\title{
Control of Mammary Function During Lactation in Crossbred Dairy Cattle in the Tropics
}

\author{
Narongsak Chaiyabutr
}

Additional information is available at the end of the chapter

http://dx.doi.org/10.5772/50763

\section{Introduction}

The major problems for the dairy practices in the tropical country are low milk yield and short lactation period of either pure exotic or crossbred dairy cattle. Many factors affect milk production in dairy cattle in tropical areas including high environmental temperature and humidity, lower genetic potential for milk production in indigenous cattle and inadequate supply of food during the dry and hot summer season. Crossbreeding of indigenous and exotic cattle for tropical use has been exploited as an efficient tool for blending the adaptability of native cattle with the high milking potential of exotic breeds resulting in increased milk production. In crossbred cattle, mechanisms of milk secretion are known to be inherited and are thought to be among the causes of differences in metabolic parameters. Milk secretion is a continuous process and requires a continuous supply of substrates for milk productions. Short persistency of lactation is the low ability of cow to continue producing milk at a high level after the peak of lactation. Improved persistency of lactation can contribute to decreasing the cost of the production system because lactation persistency is associated with feeding and health costs including reproductive performance. (Sölkner \& Fuchs,1987). There are many different ways to improve persistency of lactation, e.g. during summer, different types of crop residues have been used to feed animals as roughage in attempting to improve dairy productivity during period of scarcity (Jayasuriya \& Perera, 1982; Promma et al., 1994). However, there is considerable evidence that understanding the mechanism acting within the body in relation to the control of milk secretion may improve of milk production in crossbred dairy cattle in tropics.

It is well known that mammary growth during pregnancy is a prerequisite for satisfactory lactation in all mammals. During pregnancy, the mammary gland is competing with many other organs for nutrition to sustain growth. Mammary secretory activity in dairy cattle is initiated from pregnancy although it is at a low level. Experimental studies in both periods of 
pregnancy and lactation will give some clue as to the nature of the developed mechanism of the mammary gland. During pregnancy, maternal bodily functions are altered, e.g. cardiac output and heart rate, while during lactation, many bodily functions are also altered, e.g. general circulation and body fluid (Hanwell \& Peaker, 1977). Therefore, knowledge of extramammary factors influencing milk production is essential to study in both pregnancy and period of lactation which can provide quantitative information in crossbred Holstein cattle

The lactating mammary gland is dependent upon its blood supply to provide substrates at appropriate rates to sustain milk synthesis. The rate of substrates supplying to the mammary gland is determined by substrate concentration in the plasma and mammary blood flow. There is evidence that substrate supply to the mammary gland is often inadequate to maintain the maximum rate of milk synthesis. This raises the question: do changes in bodily function (water balance, general circulation and mammary circulation) alone have an effect on milk secretion or is the effect solely due to inadequate of the utilization of substrates in the mammary gland in crossbred dairy cattle? As glucose is the principal precursor of lactose, the decrease in milk lactose can be explained by a change of the mammary utilization of glucose (Faulkner \& Peaker, 1987). Lactose is a highly osmotic component, which allows the drainage of water from blood to the alveolar compartment. As such, it is the principal milk component regulating the volume of milk production. Glucose is known to play an important role not only in lactose synthesis but also providing the reducing equivalent required for the synthesis of fatty acid de novo in the mammary gland (Chaiyabutr et al., 1980). Very few data are available regarding the dynamics and the regulation of glucose metabolism in whole body and the mammary gland of different types of crossbred cattle. Insight into the study in the utilization of glucose metabolism for synthesis of milk components in different metabolic pathways in the mammary gland, have improved understanding of what factors influencing the effect of low milk yield of crossbred dairy cattle in the tropics.

The role of endocrine regulation in initiation and maintenance of lactation is known to occur in many species. However, hormonal requirement among mammalian species differ considerably, for example, in rabbit prolactin alone can maintain lactation, while in cows prolactin is not a rate limiting hormone in established lactation in place growth hormone become relatively more important (Hart, 1973; Mepham, 1993). Very few data are available in the study of circulating hormones during lactation in crossbred dairy cattle. The circulating concentrations of some hormones will be expected to change and relate to the mechanism responsible for the control of milk secretion in different types of crossbred Holstein cattle. Investigation of the plasma levels of various hormones (thyroid hormone, prolactin, cortisol, growth hormone, insulin, glucagon, progesterone and estradiol) involving milk secretion in late pregnancy and different stages of lactation may give some information on the control mechanism of milk secretion either directly or indirectly on the function of mammary gland in different types of crossbred Holstein cattle.

Thus, this chapter is intended to review the highlight the regulatory mechanisms underlying marked low milk yields, by providing an updated summary of the results obtained concerning the physiological changes in both extra-mammary factors and intra-mammary factors of 
crossbred Holstein cows between 50HF:50Red Sindhi(50\%HF) and 87.5HF:12.5RS(87.5\%HF) cattle in the tropics

\section{Water metabolism and mammary circulation in different stages of lactation of crossbred cattle}

It is known that lactating dairy cows metabolize large amounts of water and are affected rapidly by water deprivation (Murphy 1992). In the tropics, dairy cattle utilize body water to maintain homeostasis in the mechanisms of thermoregulation and lactation. The effect of excessive heat load in high environment temperature leading to increase in heat dissipation (Hahn et al., 1999), which may lead to a loss body water and decrease in milk yield in lactating cattle. However, an increase in water intake during lactation closely match to increase in water secrete in milk, since milk composition has about $87 \%$ of water. During lactation, many bodily functions are altered; for example, blood volume and cardiac output are increased (Hanwell \& Peaker 1977). These changes may effectively alter body fluid and thus circulatory distribution including the blood supply to the mammary gland.

\subsection{Water metabolism}

\subsubsection{Measurement of water metabolism}

In this section, a brief description of methods for measuring water metabolism is presented. According to the study of Chaiyabutr et al., (1997) in measurements of water metabolism, the water turnover rate (WTO), total body water (TBW) in dairy cattle were performed using tritiated water dilution techniques. Briefly, the dairy cattle was injected intravenously with carrier free tritiated water in normal saline at a single dose of 3,000 $\mu \mathrm{Ci}$ per animal. The equilibration time was determined by taking serial venous blood samples for 3 days after the injection. Blood samples were collected at 20, 30, 40, 50, 60 min and 4, 8, 20, 26, 32, 44, 50, 56, 68 and $74 \mathrm{~h}$ subsequent to the injection. Preparation of samples for counting was achieved by the internal standardization technique. The corrected activity of samples, in disintegrate per minute (d.p.m.), were plotted on semi-logarithmic paper against time. The dilution curve of tritiated water in plasma was described by an exponential equation using a one compartment model, which is

$$
\mathrm{Yi}=\mathrm{Ae} \mathrm{-}^{\mathrm{klt}} \text {, }
$$

where $\mathrm{Y}$ is concentration of tritium in plasma at time $\mathrm{t}(\mathrm{nci} / \mathrm{ml})$; $\mathrm{A}$ is plasma concentration intercept 1 in nci/ml.

The extrapolated activity at theoretical zero time of complete mixing of radio-isotope was used to determine the total body water space (TOH). The TOH space was calculated:

TOH space $(\mathrm{ml})=[$ standard count $($ dis $/ \mathrm{min}) \times$ dose $(\mathrm{ml})] /$ [radio activity counts at zero time (dis/min)].

The biological half-life of tritium-labelled water (T 1/2) was determined from the slope of the linear regression line obtained from plot on semi-logarithmic paper of the activity of the 
samples taken over the period of 3 days against time. The water turnover rate was calculated from the equation:

$$
\text { WTO }(1 / \text { day })=0.693 \times \text { TOH space } / \mathrm{T} 1 / 2 .
$$

Total body water (TBW) was calculated by using the corrected factor (1 - fraction of plasma solids) x TOH space (Chaiyabutr et al. 1997).

Work on water metabolism has produced some interesting results. The regulation of body fluids and mammary circulation in different types of crossbred Holstein Friesians (HF) cattle showed some differences between $50 \% \mathrm{HF}$ and $87.5 \% \mathrm{HF}$ cattle during late pregnancy and lactation (Chaiyabutr et al., 1997). A short persistency of milk yield during the transition period from early to mid lactation has been observed in $87.5 \% \mathrm{HF}$ cattle. In contrast to $50 \% \mathrm{HF}$ cattle, persistent lactation seemed to be apparent throughout periods of lactation (Chaiyabutr et al. 2000a). The different control mechanisms were at play in the regulation of milk production as lactation advances in $50 \% \mathrm{HF}$ and $87.5 \% \mathrm{HF}$ cattle. The $87.5 \% \mathrm{HF}$ cattle had lower efficiency in water retention mechanism and poor adaptation to tropical environment in comparison to 50\%HF (Chaiyabutr et al., 1997; 2000a). The high genetic similarity of $87.5 \% \mathrm{HF}$ cattle to the exotic bos taurus breed may lead to poor adjustment to the tropical environment, while yielding high milk production in early lactation. However, the milk yield of $87.5 \% \mathrm{HF}$ cattle has been shown to be higher in early lactation than $50 \% \mathrm{HF}$ cattle while the ratio of total dry matter intake to milk yield was lower in $87.5 \% \mathrm{HF}$ as compared to $50 \% \mathrm{HF}$ cattle. The energy output in milk and for maintenance for $87.5 \% \mathrm{HF}$ cattle was greater than the energy consumed in the food in early lactation. The $50 \% \mathrm{HF}$ cattle was approximately in energy equilibrium, there being no change in the ratio of dry matter intake to milk yield among periods of lactation.

Water is known to play a prominent role in the processes involved in the formation of milk, since milk is isoosmotic with plasma. In intra-mammary process, the net transfer of water from plasma to the alveolar lumen is directly proportional to the transfer of solute. Water is drawn into secretory vesicles because of the presence of osmotically active lactose (Kaufmann \& Hagemeister,1987; Linzell \& Peaker, 1971),which is formed in the golgi apparatus of the lactating cells. Thus, the amount of water secreted into milk is regulated by the rate of lactose synthesis. However, cellular water metabolism in lactating cell is not a final story of the processes of milk formation. The extra-mammary factor about body water content will be a prerequisite for satisfactory lactation, which may influence on lactation persistency in crossbred cattle.

Measurements of water turnover rate and total body water using tritiated water as a marker in different stages of lactation of crossbred Holsteins cattle is shown in Fig.1 (Chaiyabutr et al.,1997; 2000a). Chaiyabutr et al (2000a) have noted that the total body water as a percentage of body weight of $87.5 \% \mathrm{HF}$ cattle was lower than $50 \% \mathrm{HF}$ cattle in all periods of lactation. This may be attributed to a relatively lower efficiency in the water retention mechanism, although the water intake was higher in $87.5 \% \mathrm{HF}$ animals during high milk 
yield. Low water content may be related to the poor adaptation of $87.5 \% \mathrm{HF}$ to the tropical environment. Poorer lactation persistency in higher yielding cows has also been noted (Chase, 1993; Coulon et al., 1995). The studies in both $87.5 \% \mathrm{HF}$ and 50\%HF housing in the same shed under the same environment by Chaiyabutr et al., (2000a) have shown that a lower water turnover rate was apparent especially in late lactation of the $87.5 \% \mathrm{HF}$ cattle in comparison with $50 \% \mathrm{HF}$ cattle.
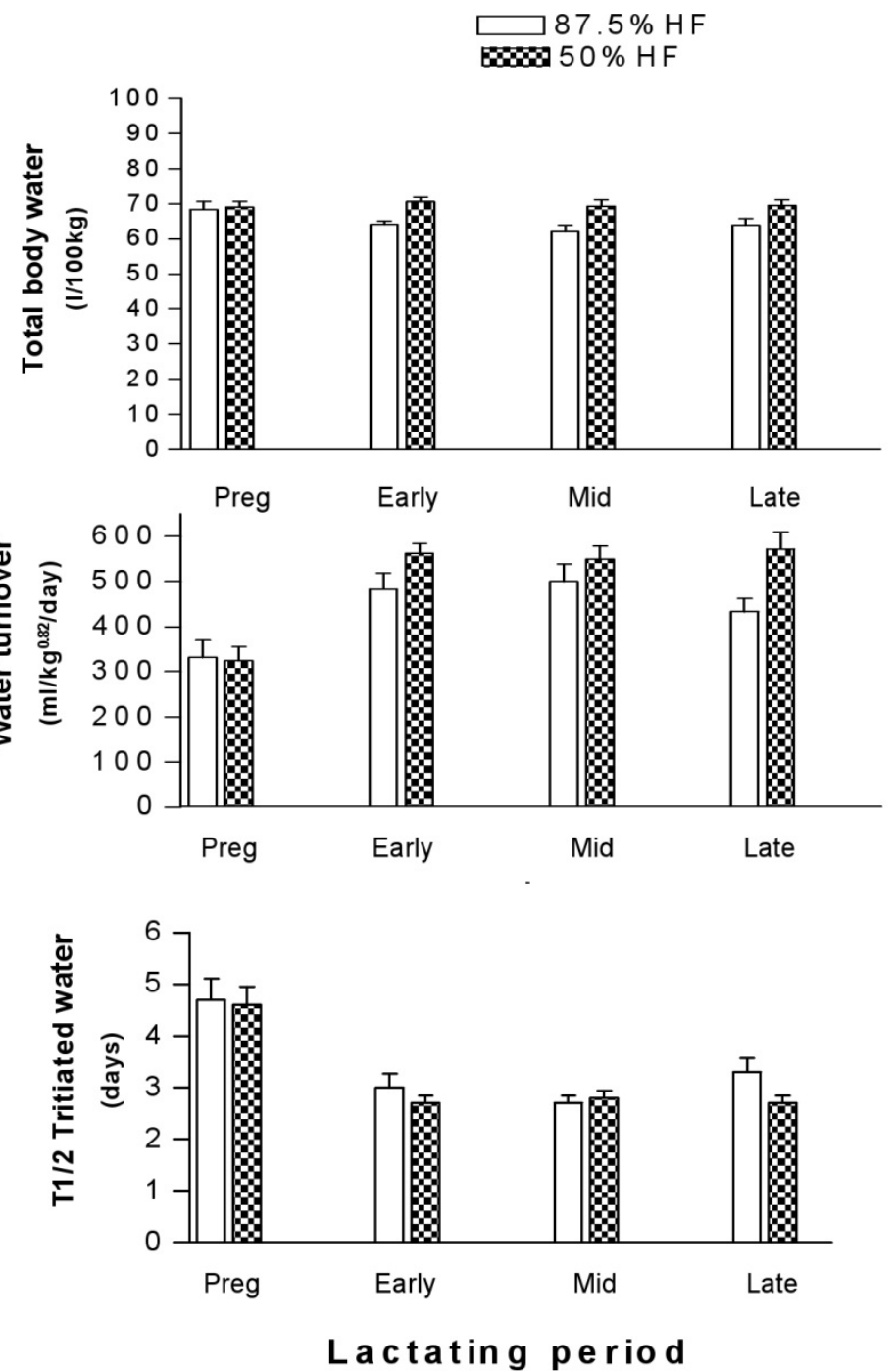

Figure 1. Water turnover rate, total body water and half-life of tritiated of water during late pregnancy and lactation of $87.5 \% \mathrm{HF}$ and $50 \% \mathrm{HF}$ cattle in tropical environment. (Data from Chaiyabutr et al., 1997; 2000a). 
The water turnover rate of both types of crossbred cattle was not influenced by environmental conditions, although marked differences of water turnover rate and half-life of body water in animals have been reported during the winter and summer (Ranjhan et al., 1982). A higher water reserve in $50 \% \mathrm{HF}$ cattle would not only provide a higher reservoir of soluble metabolites for biosynthesis of milk but was also useful in slowing down the elevation in body temperature of this breed during lactation in hot conditions (Nakamura et al.,1993). The $87.5 \%$ HF cattle did not require greater amounts of water, while it could restore their body fluids to equilibrium in all lactating periods. The differences between crossbred and purebred animals in body composition and water turnover rate have also been reported (Macfarlane \& Howard 1970). The study of the regulation of body fluid and mammary circulation during late pregnancy and early lactation of crossbred Holstein cattle by Chaiyabutr et al., (1997) have found that the water turnover rate was significantly higher approximately $45 \%$ in lactating cattle than in pregnant cattle in either $87.5 \% \mathrm{HF}$ or $50 \% \mathrm{HF}$ cattle. During the lactating period the half-life of tritiated water (2.9 days) was significantly lower than pregnant period (4.7 days).

\subsection{Mammary circulation and blood volume}

\subsubsection{Measurement of udder blood flow}

According to the study of Chaiyabutr et al., (1997), the measurement of udder blood flow in dairy cattle was described. Briefly, blood flow through half of the udder was determined by measuring the dilution of dye T-1824 (Evans blue) by a short term continuous infusion in the milk vein of dairy cattle. A dye (T-1824) was dissolved in sterile normal saline and diluted to a concentration of $100 \mathrm{mg} / \mathrm{l}$. The solution was infused by a peristaltic pump at a constant rate of $80 \mathrm{ml} / \mathrm{min}$ into the milk vein for 1-2 min. Before infusion, blood was drawn from downstream in the milk vein as a pre-infusion sample. About 10 seconds after starting infusion, $10 \mathrm{ml}$ of blood was drawn from downstream in the milk vein at a constant rate into a heparinized tube. Two consecutive plasma samples were taken during dye infusion. Blood flow of half of the udder was calculated from the concentration of dye in plasma samples using the equation derived by Thompson \& Thomson (1977). In lactating cows, quarter milking showed that the yields of the two halves of the udder were similar. Udder blood flow was therefore calculated by doubling the flow measured in one milk vein.

\subsubsection{Measurement of plasma volume and blood volume}

In the studies of plasma volume and blood volume, plasma volume was measured by dilution of Evan's blue (T-1824) dye. The injection of $20 \mathrm{ml}$ of the dye $(0.5 \mathrm{~g} / 100 \mathrm{ml}$ normal saline) into the ear vein catheter was performed and venous blood samples were collected from the jugular vein at 30, 40 and $50 \mathrm{~min}$ after dye injection. Dilution of dye at zero time was determined by extrapolation. Blood volume was calculated from the plasma volume and packed cell volume (PCV). Plasma osmolality was measured using the freezing point depression method. 
The results of study by Chaiyabutr et al (2000a) have noted that the mammary circulation of crossbred dairy cattle between $87.5 \% \mathrm{HF}$ and $50 \% \mathrm{HF}$ varied during different periods of lactation. Mammary blood flow is known to be a major determinant controlling milk production in a way to carry milk precursors to the mammary gland at the process of milk synthesis. A decrease in blood flow to the mammary gland coinciding with a short persistency of milk yield during the transition period from early to mid lactation occurred in $87.5 \% \mathrm{HF}$ cattle (Chaiyabutr et al. 2000a). The milk yield of $87.5 \% \mathrm{HF}$ cattle significantly declined in mid-lactation from early lactation. In contrast to $50 \% \mathrm{HF}$ cattle, short persistent lactation seemed to be apparent throughout periods of lactation (Fig. 3). The study for alteration of lactation persistency in different crossbred animals will throw some light on a useful index for studying adaptability in crossbred cattle, which will provide information on choosing suitable crossbred dairy cattle in the tropics. A higher mammary blood flow during early lactation compared to mid-lactation in $87.5 \% \mathrm{HF}$ cattle could not be attributed to a change in blood volume and plasma volume, which remained nearly constant (Fig.2). Plasma osmolality remained unchanged during the course of lactation in both $87.5 \% \mathrm{HF}$ and $50 \% \mathrm{HF}$ cattle indicating that homeostasis was being maintained throughout all periods of lactation. Such differences of the mammary circulation between $87.5 \% \mathrm{HF}$ and $50 \% \mathrm{HF}$ animals can be attributable to disparities in breed. The ratio of mammary blood flow to the rate of milk yield did not change during the course of lactation in 50\% HF animals. The marked decrease in the mammary blood flow of $87.5 \% \mathrm{HF}$ at mid-lactation would correlate with the decrease of milk yield. The decline in milk yield after the peak will be due primarily to a decreased availability of substrates to the mammary gland. The marked increase in the ratio of mammary blood flow to the rate of milk yield during lactation advance to mid-lactation (548:1) and late lactation (668:1) in $87.5 \% \mathrm{HF}$ cattle indicated a more decreased secretory activity of mammary tissue. The question then arises as to whether mammary metabolism influences mammary blood flow or mammary blood flow influences mammary metabolism.

Many studies on mechanisms concerned with regulation of mammary blood flow, local and extra-mammary production of vasoactive agents and activity of mammary sympathetic nerves have been reviewed comprehensively (Linzell, 1974). The study on mammary circulation in relation to the general circulation of crossbred cattle at different stages of lactation is shown in Fig. 3. The mean values of mammary resistance (the ratio of mean arterial pressure to mammary blood flow) did not significant change in different periods of lactation in either $87.5 \% \mathrm{HF}$ or $50 \% \mathrm{HF}$ cattle. It is clear that the local changes for vasoconstriction in the udder were not apparent in different periods of lactation for both types of crossbred cattle. This proposal was indicated that humoral factors were responsible, especially the level of plasma growth hormone in the regulation of mammary circulation and milk production between $87.5 \% \mathrm{HF}$ and $50 \% \mathrm{HF}$ cattle. A number of studies have demonstrated that similar proportion increases in milk secretion and mammary blood flow occurred during growth hormone treatment in goats and cows (Hart et al., 1980; Chaiyabutr et al 2007). A marked decline in blood flow to the mammary gland during the transitional period from early lactation to mid-lactation in $87.5 \% \mathrm{HF}$ cattle with the constancy of the plasma volume and blood volume were apparent (Chaiyabutr et al 2000a). Regulation of 
mammary blood flow from the early lactation to mid-lactation in $87.5 \% \mathrm{HF}$ cattle may be regarded a major homeorhetic principle (Bauman \& Currie, 1980).

Mammary growth during pregnancy has been known to be a prerequisite for satisfactory lactation. The degree of local vasoconstriction was greater during pregnancy and less in lactation for both types of crossbred cattle. In late pregnancy, the mammary circulation of
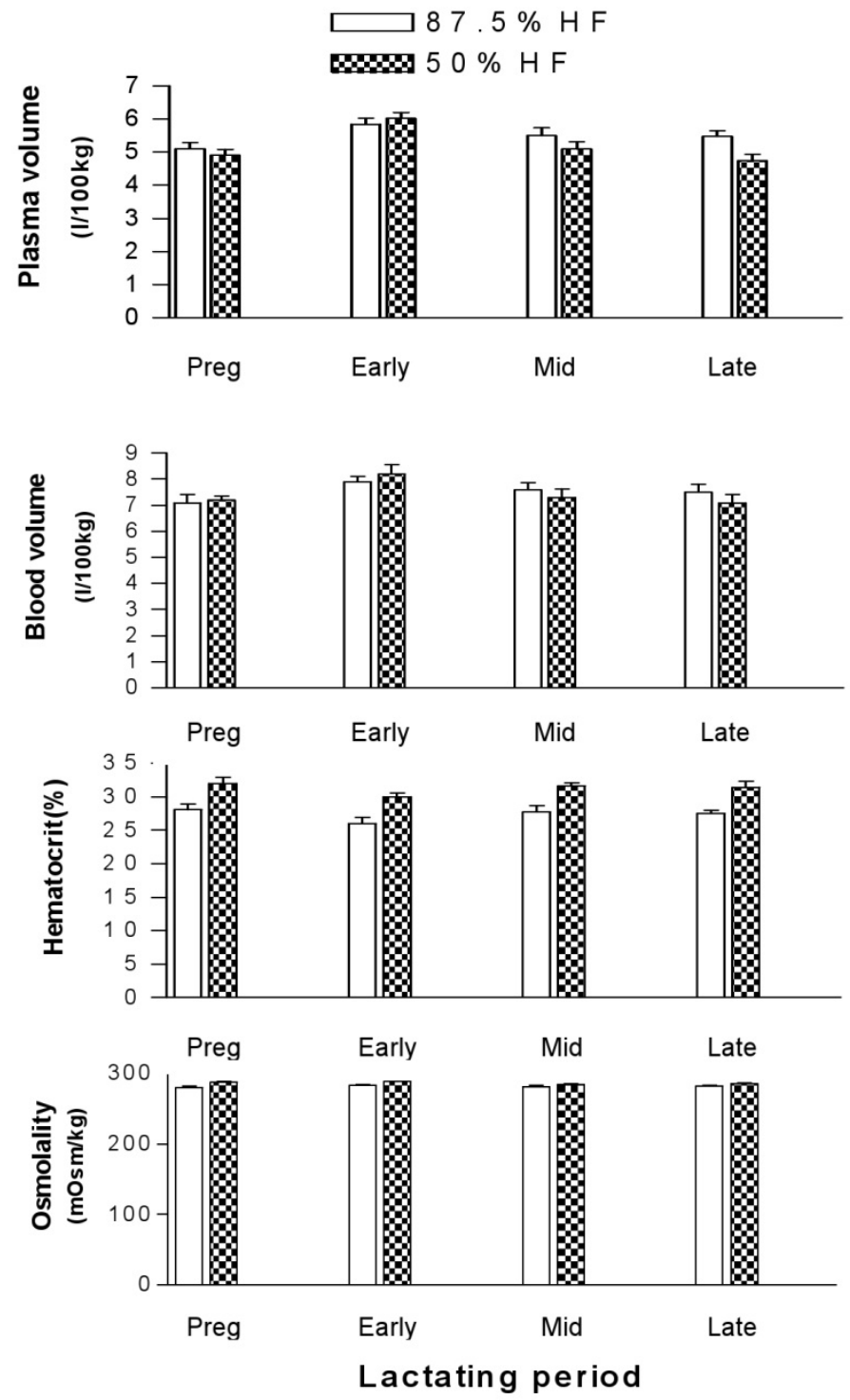

Figure 2. Plasma volume, blood volume, hematocrit and plasma osmolality during late pregnancy and lactation of $87.5 \% \mathrm{HF}$ and 50\%HF cattle in tropical environment. (Data from Chaiyabutr et al., 1997; 2000a). 


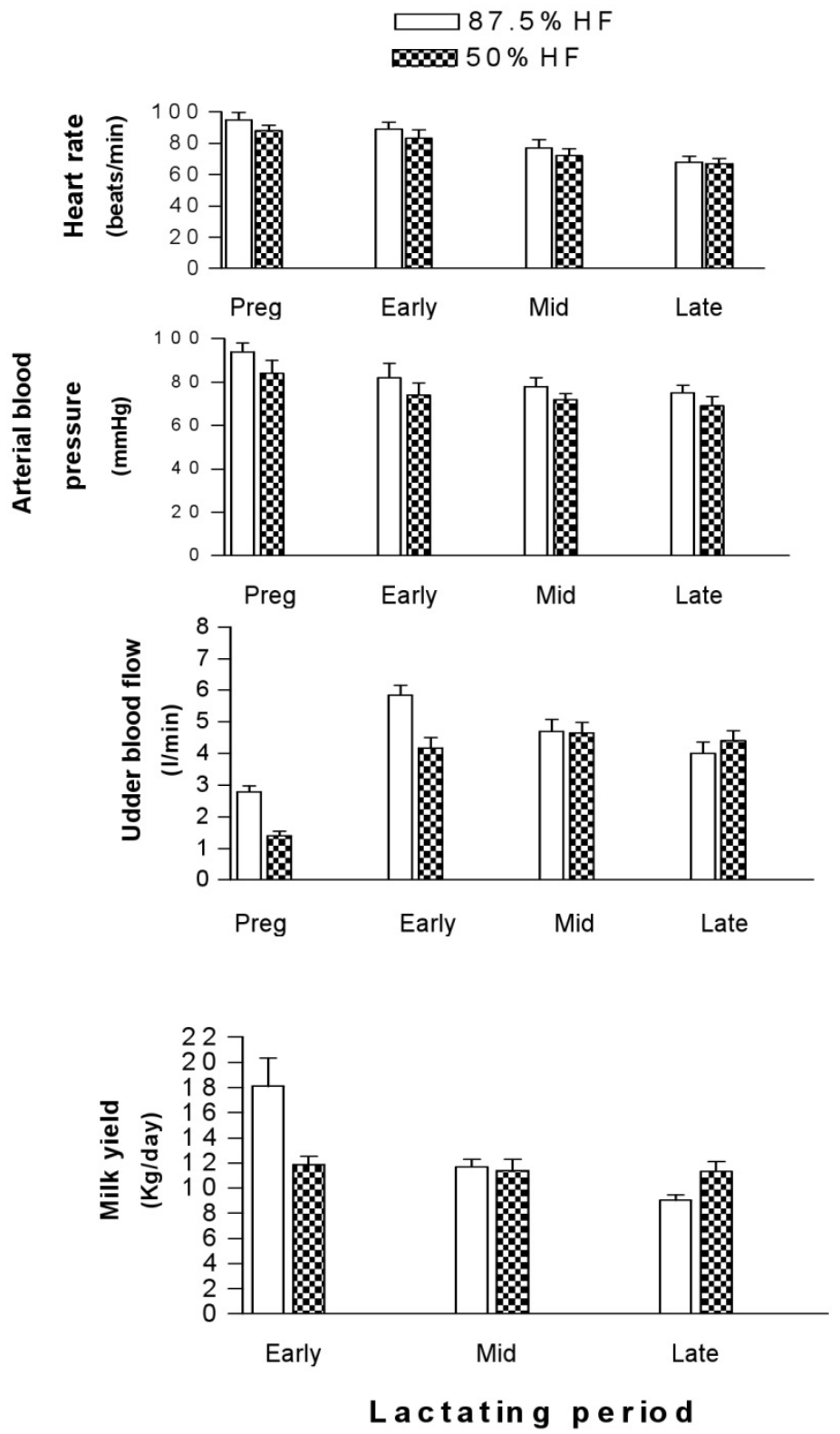

Figure 3. The mean arterial pressure, heart rate, udder blood flow and milk yield during late pregnancy and lactation of $87.5 \% \mathrm{HF}$ and $50 \% \mathrm{HF}$ cattle in tropical environment. (Data from Chaiyabutr et al., 1997; 2000a).

$50 \% \mathrm{HF}$ was less than $87.5 \% \mathrm{HF}$ cattle which could be due to variations in the developments of mammary blood vessels and mammary cells. The high genetic blood level closing to the 
exotic bos taurus breed of $87.5 \% \mathrm{HF}$ animals may cause a rapid rate in the development of the secretory activity of the mammary cell in the late pregnancy. Local vasodilatation produced by the active cells (Hanwell \& Peaker, 1977; Lacasse et al., 1996) would decrease in the resistance of the vascular bed and a higher mammary blood flow of $87.5 \% \mathrm{HF}$ in comparison with $50 \%$ HF cattle (Chaiyabutr et al., 2000a). These physiological changes would accompany with increases in plasma volume and blood volume in the lactating period when compared with the pregnant period in either $87.5 \% \mathrm{HF}$ or $50 \% \mathrm{HF}$ cattle. These changes are agree to other reports that blood volume, plasma volume and water turnover are markedly higher in lactating animals than in pregnant animals (Hanwell \& Peaker, 1977; MacFarlane \& Howard, 1970). The packed cell volume significantly decreased in the lactating period of $87.5 \% \mathrm{HF}$ animals while it did not significantly change in $50 \% \mathrm{HF}$ animals. The packed cell volume of $50 \% \mathrm{HF}$ animals was significantly higher than that of $87.5 \% \mathrm{HF}$ animals.

There were no significant differences in heart rate, arterial blood pressure and plasma osmolality between the periods of late pregnancy and early stage of lactation in either $87.5 \% \mathrm{HF}$ or $50 \% \mathrm{HF}$ cattle. Udder blood flow was nearly three times higher in lactating period than in late pregnant period in either $87.5 \% \mathrm{HF}$ or $50 \% \mathrm{HF}$ cattle. The udder blood flow of $87.5 \% \mathrm{HF}$ was significantly higher while mammary resistance was significantly lower than in $50 \% \mathrm{HF}$ animals. Milk secretion in early lactation of $87.5 \% \mathrm{HF}$ animals was higher than that of $50 \% \mathrm{HF}$ animals. The ratio of DM intake to milk production for $87.5 \% \mathrm{HF}$ animals was lower than that of $50 \% \mathrm{HF}$ animals. From these results it can be concluded the difference between breeds was found in $87.5 \% \mathrm{HF}$ animals which had a higher milk yield but a lower adjustment for the regulation of body fluids during pregnancy and lactation in comparison to $50 \% \mathrm{HF}$ animals.

\section{Role of substrates supply for milk production}

It is known that the rate of substrates supplying to mammary gland is determined by substrate concentration in the plasma and mammary blood flow. The sustainable milk synthesis in the mammary gland is dependent upon its blood supply to provide substrates at appropriate rates. There is evident that substrate supply to the mammary gland is often inadequate to maintain the maximum rate of milk synthesis (Linzell \& Mepham 1974). The mammary gland may be producing milk at a rate below its potential. The rate of milk production depends on function of number of secretory cells and their metabolic activity. However, the mechanisms can be devided into three main levels of regulation, which are the arterial flow of substrates in the mammary gland, the substrate extraction by the mammary gland and the metabolic and secretion activities of the mammary epithelial cell.

\subsection{Changes of substrates supply}

\subsubsection{Measurement of mammary uptake of substrates}

According to the study of Chaiyabutr et al., (2002), the measurement of udder blood flow in dairy cattle was described. Briefly, The uptake of substrate by the udder (Us), expressed as $\mu \mathrm{mol} / \mathrm{min}$, was calculated from the equation: 


$$
\mathrm{US}_{\mathrm{S}}=\operatorname{MPFx}\left(\mathrm{PA}_{\mathrm{A}} \mathrm{PV}\right)
$$

The substrate extraction by the mammary (Es):

$$
\mathrm{Es}=\left(\mathrm{PA}_{\mathrm{A}}-\mathrm{Pv}_{\mathrm{V}}\right) / \mathrm{PA}_{\mathrm{A}}
$$

Where:

$\mathrm{MPF}=$ Mammary plasma flow $(\mathrm{ml} / \mathrm{min})$

$\mathrm{P}_{\mathrm{A}}=$ Concentration of substrate in coccygeal arterial plasma $(\mu \mathrm{mol} / \mathrm{ml})$

$\mathrm{Pv}_{\mathrm{v}}=$ Concentration of substrate of plasma from milk vein $(\mu \mathrm{mol} / \mathrm{ml})$

The results of study by Chaiyabutr et al (2002) in both $87.5 \% \mathrm{HF}$ and $50 \% \mathrm{HF}$ cattle have shown that the mammary uptake of many substrates between late pregnancy and lactating periods in crossbred HF cattle was not based on changes in arteriovenous concentration differences and extraction ratio. Mammary growth during pregnancy has been known to be a prerequisite for satisfactory lactation. The pattern of mammary growth varied during pregnancy and early lactation for both $87.5 \% \mathrm{HF}$ and $50 \% \mathrm{HF}$ cattle. Changes of substrates across the udder will account for changes in mammary blood flow. Both $87.5 \% \mathrm{HF}$ and $50 \% \mathrm{HF}$ cattle showed the low values of both arteriovenous concentration differences of substrates across the mammary gland and mammary extraction ratio during late pregnancy, which differ from the lactating period with a marked increase of mammary uptake of substrates for milk synthesis.

Volatile fatty acid in form of acetate is known to be the major of source energy of normal fed ruminants. No differences in mammary arteriovenous concentration differences and extraction ratio of acetate have been shown between late pregnancy and lactation in both $87.5 \% \mathrm{HF}$ and $50 \% \mathrm{HF}$ cattle. The low rate of mammary uptakes for acetate during pregnancy was dependent upon rate of blood flow. During late pregnancy, circulating $\beta$ hydroxybutyrate level which arise mainly from rumen butyrate in the normal fed animal (Leng \& West, 1969). There were no obvious of arteriovenous concentration differences and extraction ratio of $\beta$-hydroxybutyrate across the mammary gland of both $50 \% \mathrm{HF}$ and $87.5 \%$ HFcattle.

The concentrations of arterial plasma free fatty acid and triacylglycerol increased in the late pregnancy of both $50 \% \mathrm{HF}$ and $87.5 \% \mathrm{HF}$ cattle and were more sensitive to alteration than other blood substrates; this phenomenon has been proposed as an indication of undernutrition (Reid \& Hinks, 1962). The mobilization of body fat in late pregnancy occurs in response to hormonal secretion (Lindsay, 1973). It would be a physiological phenomenon, not a consequence of under-nutrition. The measurement of arteriovenous differences of FFA across the mammary gland together with mammary blood flow did not provide a quantitative estimation of their total uptake by mammary tissue in either $50 \% \mathrm{HF}$ and $87.5 \% \mathrm{HF}$ cattle, since the release of FFA into venous blood due to triacylglycerol hydrolysis during the uptake of plasma triacylglycerol as in lactation has been noted (West et al., 1967). During the development of the mammary gland in normal late pregnancy, an occurring the 
utilization of FFA may cause changes in arteriovenous differences, the extraction ratio and net uptake of FFA. The net uptake of triacylglycerol by the mammary gland significantly increased in lactating period in comparison to the late pregnancy in both $87.5 \% \mathrm{HF}$ and $50 \% \mathrm{HF}$ cattle. It is possible that a change for releasing of FFA is a result of changes of enzymatic activity of lipoprotein lipase in the mammary tissue. This enzyme activity has been reported to be higher in lactating bovine mammary tissue relative to pregnant tissue (Shirley et al., 1973).

\subsection{Glucose metabolism and glucose utilization in the mammary gland}

It is known that an increase of milk yield can be achieved only by increasing the rate of lactose synthesis. The lactating udder utilizes most of the glucose entering the circulation of ruminants and irreversible glucose loss from plasma is highly correlated with lactose output (Bickerstaffe et al., 1974; Horsfield et al., 1974). The role of glucose in regulating milk secretion has also been demonstrated in the isolated perfused udder (Hardwick et al., 1961). The regulation of the milk yield of animals is therefore mainly based on the mechanisms governing the quantity of glucose extracted by the udder and converted into lactose. The metabolic fate of glucose metabolism will consider the utilization in the whole body relating to the utilization in the mammary gland in either pregnancy or lactation.

\subsubsection{Measurements of Glucose kinetic and glucose utilization in the mammary gland}

According to Chaiyabutr et al.,(2000c), body glucose metabolism and intramammary glucose metabolism has been described. In brief, glucose kinetic studies at different stages of lactation were carried out by using continuous infusion of both $\left[\mathrm{U}-{ }^{14} \mathrm{C}\right]$-glucose and $\left[3-{ }^{3} \mathrm{H}\right]-$ glucose solution. A priming dose of radioactive glucose in $20 \mathrm{ml}$ of normal saline containing $30 \mu \mathrm{Ci}\left[3-{ }^{3} \mathrm{H}\right]$-glucose and $15 \mu \mathrm{Ci}\left[\mathrm{U}-{ }^{14} \mathrm{C}\right]$-glucose was administered intravenously via the ear vein catheter and followed by a continuous infusion(using Peristatic pump) of 1 $\mathrm{ml} / \mathrm{min}$ of normal saline solution $(0.9 \%)$ containing $0.7 \mu \mathrm{Ci} / \mathrm{ml}$ of $\left[\mathrm{U}-{ }^{14} \mathrm{C}\right]$-glucose and 1.5 $\mu \mathrm{Ci} / \mathrm{ml}$ of $\left[3-{ }^{3} \mathrm{H}\right]$-glucose for $3 \mathrm{~h}$. During the last $1 \mathrm{~h}$ of continuous infusion, three sets of blood samples were collected at 20 min intervals.

The glucose turnover rate in the whole animal (T), expressed as $\mu \mathrm{mol} / \mathrm{min}$, was calculated from the equation:

$$
\mathrm{T}=\mathrm{I} / \mathrm{GA}_{\mathrm{A}}
$$

where, $\mathrm{I}=$ rate of infusion of $\left[\mathrm{U}-{ }^{14} \mathrm{C}\right]$ glucose or $\left[3-{ }^{3} \mathrm{H}\right]$ glucose $(\mu \mathrm{Ci} / \mathrm{min})$ and $\mathrm{G}_{\mathrm{A}}=$ specific activity of ${ }^{14} \mathrm{C}$ - or ${ }^{3} \mathrm{H}$-glucose in arterial plasma at equilibrium $(\mu \mathrm{Ci} / \mu \mathrm{mol})$.

Recycling of glucose carbon in the whole animal, expressed as \% glucose turnover, was calculated from the equation:

$$
\text { Recycling }=\left(\mathrm{T}_{3}-\mathrm{T}_{14}\right) \times 100 / \mathrm{T}_{3}
$$

Where: 
$\mathrm{T}_{3}=$ Reversible turnover of glucose calculated from $\left[3-{ }^{3} \mathrm{H}\right]$ glucose

$\mathrm{T}_{14}=$ Irreversible turnover of glucose calculated from $\left[\mathrm{U}-{ }^{14} \mathrm{C}\right]$ glucose

Uptake of glucose by the udder $\left(\mathrm{U}_{\mathrm{G}}\right)$, expressed as $\mu \mathrm{mol} / \mathrm{min}$, was calculated from the equation:

$$
\mathrm{UG}_{\mathrm{G}}=\mathrm{MPFx}(\mathrm{PAPv})
$$

Where:

$\mathrm{MPF}=$ Mammary plasma flow $(\mathrm{ml} / \mathrm{min})$

$\mathrm{P}_{\mathrm{A}}=$ Concentration of glucose in coccygeal arterial plasma $(\mu \mathrm{mol} / \mathrm{ml})$

$\mathrm{P}_{\mathrm{v}}=$ Concentration of glucose of plasma from milk vein $(\mu \mathrm{mol} / \mathrm{ml})$

The milk component output (MO), expressed as $\mu \mathrm{mol} / \mathrm{min}$ and was calculated from the equation:

$$
\mathrm{MO}=\mathrm{Ms} \times \mathrm{Cc} / 1000
$$

Where:

Ms $=$ Milk secretion rate $(\mathrm{ml} / \mathrm{min})$

$\mathrm{C} c=$ Concentration of components in milk $(\mu \mathrm{mol} / \mathrm{L})$

Incorporation (A) of radioactivity from glucose into milk components was calculated from the equation:

$$
\mathrm{A}=\mathrm{MA}_{\mathrm{A}} / \mathrm{G}_{\mathrm{A}} \times \mathrm{t}
$$

Where:

$\mathrm{A}=$ Incorporation of radioactivity from glucose into milk components $(\mu \mathrm{mol} / \mathrm{min})$

$\mathrm{M}_{\mathrm{A}}=$ Total activity of ${ }^{3} \mathrm{H}$ or ${ }^{14} \mathrm{C}$ in the milk components $(\mu \mathrm{Ci})$

$\mathrm{G}_{\mathrm{A}}=$ Specific activity of ${ }^{14} \mathrm{C}$-or ${ }^{3} \mathrm{H}$-glucose in arterial plasma at equilibrium $(\mu \mathrm{Ci} / \mu \mathrm{mol})$

$\mathrm{t}=$ Time of infusion $(\mathrm{min})$

On the glucose kinetics studies using $3-\left[{ }^{3} \mathrm{H}\right]$ glucose and $\left[\mathrm{U}-{ }^{14} \mathrm{C}\right]$ glucose infusion, the total glucose entry rate (the reversible turnover rate of $3-\left[{ }^{3} \mathrm{H}\right]$ glucose) and utilization rates of glucose (the irreversible turnover rate of $\left[\mathrm{U}-{ }^{14} \mathrm{C}\right]$ glucose) increased significantly during early lactation in comparison to late pregnancy for both $50 \% \mathrm{HF}$ and $87.5 \% \mathrm{HF}$ cattle (Fig.4). Recycling of glucose-C was approximately $20 \%$ in both crossbred cattle which was unaffected by the stage of late pregnancy or early lactation. During late lactation, glucose carbon recycling and plasma glucose clearance increased in both $50 \% \mathrm{HF}$ and $87.5 \% \mathrm{HF}$ cattle. Comparing $50 \% \mathrm{HF}$ and $87.5 \% \mathrm{HF}$ cattle, arterial plasma glucose concentrations were slightly higher during pregnant period but significantly higher in lactating periods in $50 \%$ HF cattle (Chaiyabutr et al.,1998). This indicates that steady state conditions between the rate of utilization of glucose and the rate of gluconeogenesis differ in the body pool of glucose. The uptake, arteriovenous differences and extraction ratio for glucose across the udder increased in the lactating period in either $87.5 \% \mathrm{HF}$ or $50 \% \mathrm{HF}$ cattle. Glucose uptake 
by the udder accounted for $65 \%$ of the total glucose turnover rate in $87.5 \% \mathrm{HF}$ cattle and $46 \%$ in lactating $50 \% \mathrm{HF}$ cattle, although both crossbred cattle exhibited the same body glucose turnover rate (Chaiyabutr et al., 2000b). The $87.5 \% \mathrm{HF}$ cattle had high milk yield, body glucose metabolism and udder glucose metabolisms as compared with $50 \% \mathrm{HF}$ cattle in early lactation.
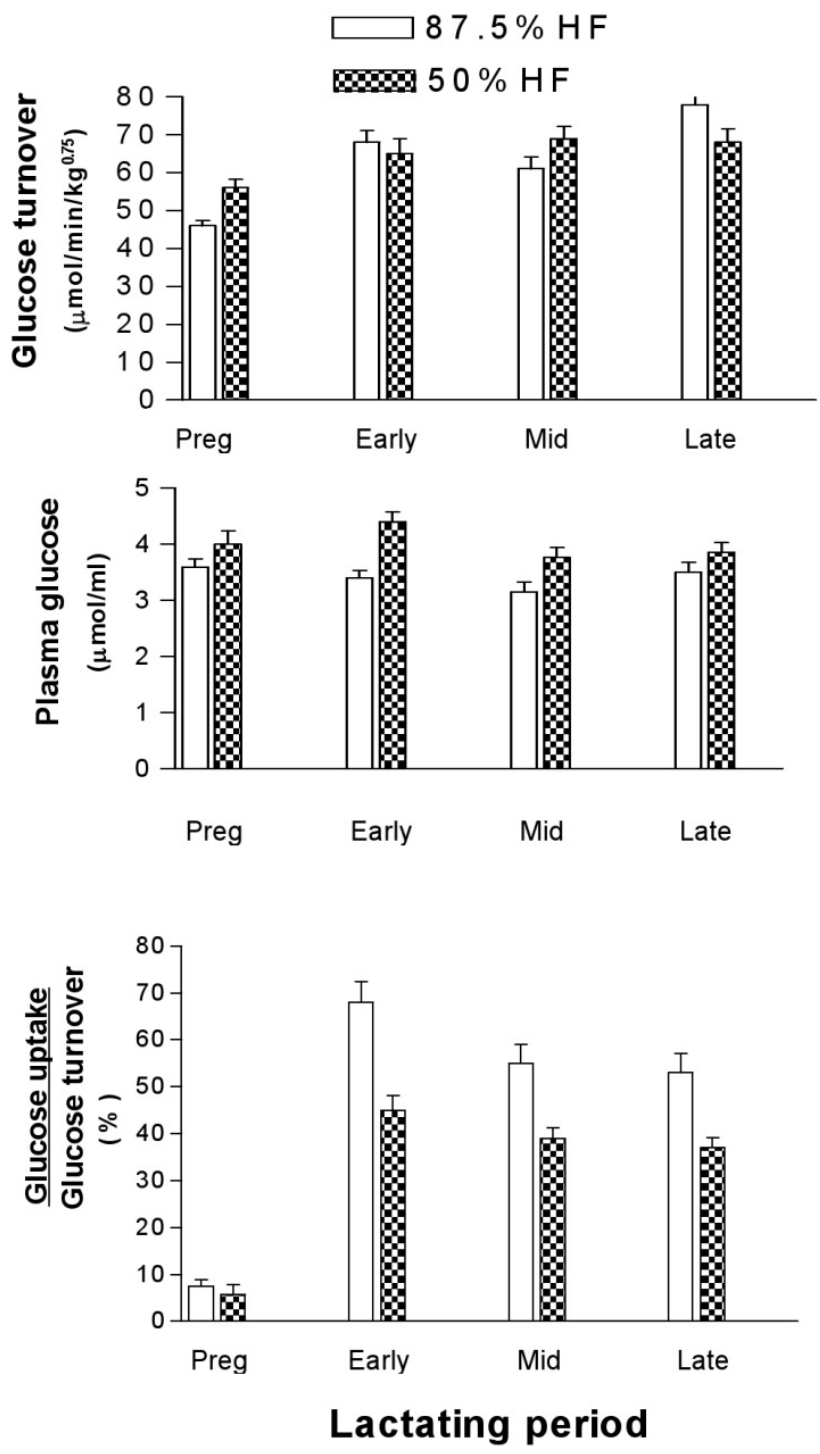

Figure 4. Glucose turnover, plasma glucose concentration and percentage of glucose uptake to glucose turnover during late pregnancy and lactation of $87.5 \% \mathrm{HF}$ and $50 \% \mathrm{HF}$ cattle in tropical environment. (Data from Chaiyabutr et al., 1998; 2000b). 
In early lactation, the high milk yields and lactose secretion of $87.5 \% \mathrm{HF}$ cattle were related to glucose uptake by the udder and udder blood flow as compared with 50\%HF cattle. An increase in udder blood flow during early lactation was higher in $87.5 \% \mathrm{HF}$ cattle than in $50 \%$ HF cattle. The marked decreases in udder blood flow, glucose uptake, lactose secretion and milk yield of $87.5 \% \mathrm{HF}$ cattle were apparent in mid- and late lactation. In contrast to $50 \% \mathrm{HF}$ cattle, no alterations for udder blood flow, udder glucose uptake, lactose secretion and milk yields were apparent throughout the course of lactation. The $87.5 \% \mathrm{HF}$ cattle had a higher milk yield but a shorter peak yield and poorer persistency in comparison with $50 \% \mathrm{HF}$ cattle (Chaiyabutr et al., 2000a). Changes in the utilization of glucose by the mammary gland for milk production in crossbred cattle would be dependent on changes in intramammary factors.

In general the rate of milk secretion is thought to be determined primarily by the secretion of lactose and consequent osmotic water movements follows lactose which create milk secretion as whole (Rook \& Wheelock, 1967; Linzell \& Peaker, 1971). An increase in milk yield can be attributed to an increase in the rate of lactose synthesis. Glucose is essential for milk secretion (Hardwick, Linzell \& Price, 1961) and glucose moiety of lactose arises directly from plasma glucose (Ebner \& Schanbacher, 1974). No differences of mammary arteriovenous differences of glucose in different periods of lactation in either $87.5 \% \mathrm{HF}$ or $50 \% \mathrm{HF}$ cattle (Chaiyabutr et al., 2000b, 2002) suggested that glucose uptake was determined mainly by mammary blood flow(Linzell, 1973). Mammary blood flow, milk yield and lactose yield were not affected by alterations of plasma glucose concentrations in both $87.5 \% \mathrm{HF}$ and $50 \% \mathrm{HF}$ cattle (Chaiyabutr et al. 2000b). There is evidence to confirm that the plasma glucose concentration is not a major factor in determining lactose output. The major change would occur in the metabolism of the mammary epithelial cell in different periods of lactation. It might be reasonable to believe that the reduction of glucose uptake by the mammary gland during mid- and late lactation of $87.5 \% \mathrm{HF}$ cattle would not be a result of the decrease in the rate of phosphorylation of glucose by hexokinase. The decrease in mammary glucose uptake has been shown to be insulin independent. The plasma insulin concentrations of both $87.5 \% \mathrm{HF}$ and $50 \% \mathrm{HF}$ cattle showed similar ranges in different periods of lactation (Chaiyabutr et al., 2000d). Transport of glucose in the mammary gland is known to be a rate-limiting step for milk synthesis which relates to glucose transporters in the acinar cell (Burnol et al., 1990). Thus, the extraction efficiency of glucose by the mammary gland would depend mainly on the capacity for transmembrane transport and/or intracellular metabolism of glucose. However, in mammary epithelial cells of ruminants, the GLUT1 transporter protein predominating in the bovine mammary gland under normal physiological conditions (Komatsu et al, 2005; Zhao et al., 1996) is probably never saturated. The regulation of glucose extraction by bovine mammary epithelial cells may occur at another level than transmembrane transport (Xiao \& Cant, 2003).

According to Chaiyabutr et al. (2000c), the studies of glucose utilization in the mammary cell using $3-\left[{ }^{3} \mathrm{H}\right]$ glucose and $\left[\mathrm{U}-{ }^{14} \mathrm{C}\right]$ glucose as markers were performed in $87.5 \% \mathrm{HF}$ and $50 \% \mathrm{HF}$ cattle. Then, incorporation of radioactive glucose from blood into milk components, the uptake of glucose including other substrates and milk components output were calculated and expressed as $\mu \mathrm{mol} / \mathrm{min}$. in the metabolic pathway. As schemes shown in Fig. $5 \& 6$, the quantitative utilization of the glucose taken up by the mammary gland for the 
synthesis of lactose, metabolize via the pentose phosphate pathway, Embden-Meyerhof pathway and the tricarboxylic acid cycle showed differences between $87.5 \% \mathrm{HF}$ and $50 \% \mathrm{HF}$ cattle. The calculated percentage of metabolism of glucose 6-phosphate pool to galactose moiety of lactose during early lactation was about $92 \%$ in $87.5 \% \mathrm{HF}$ cattle and $80 \%$ in $50 \% \mathrm{HF}$ cattle (Chaiyabutr et al 2000c). The percentages of these values were consistent with the results reported in normally fed goats and bos Taurus cows (Wood et al., 1965; Linzell, 1968). During lactation advance to late lactation, the percentages of these values decreased markedly in $87.5 \% \mathrm{HF}$ cattle. The synthesis of lactose usually involves combination of glucose and UDP-galactose; the UDP-galactose originates from glucose-6-phosphate (Ebner \& Schanbacher, 1974). The availability of cytosolic glucose 6-phosphate in the cell is usually sufficient to account for the cytosolic lactose synthesis in all periods of lactation. In mid- and late lactation of $87.5 \% \mathrm{HF}$ cattle, a decrease in the process of lactose biosynthesis might result of it impaired synthesis. The mammary gland cannot synthesize its own glucose, since the activity of glucose 6-phosphatase is low or absent in the mammary tissue (Davis \& Bauman, 1974), reducing the chance for reversibility of the glucose 6-phosphate to glucose reaction. It is possible that a decrease in the process of lactose biosynthesis may occur at the last step catalyzed by lactose synthetase (Jones, 1978), and at the same time there is an increase in cytosolic concentration of glucose 6-phosphate. The reduction of glucose uptake during lactation advance in $87.5 \% \mathrm{HF}$ cattle might be due to the inhibition of the enzyme hexokinase by high cytosolic concentration of glucose 6-phosphate pool. However, lactose biosynthesis is a complex process (Kuhn et al., 1980), there is still a need for more information to elucidate the changes in enzymatic activity in this particular system in different stages of lactation and in different breeds of cattle.

During the reduction in the lactose synthesis in mid- and late lactation in $87.5 \% \mathrm{HF}$ cattle, there were no significant changes in the rate of fatty acid synthesis de novo in the mammary gland (Chaiyabutr et al 2000c). In contrast to $87.5 \% \mathrm{HF}$ cattle, there was a low in the flux of glucose 6-phosphate through the pentose phosphate pathway in 50\%HF cattle (Fig. 6). The glucose taken up by the mammary gland were metabolized in the pentose phosphate pathway about $10-21 \%$ in $87.5 \%$ HFcattle and $5-7 \%$ in $50 \%$ HF cattle in early to mid lactation (Chaiyabutr et al 2000c). Glucose metabolism accounted for the NADPH production from pentose phosphate pathway required for fatty acid synthesis de novo in the udder about $21 \%$ in $87.5 \% \mathrm{HF}$ cattle and $15 \%$ in $50 \% \mathrm{HF}$ cattle. The differences in glucose and lipid metabolism between $87.5 \% \mathrm{HF}$ and $50 \% \mathrm{HF}$ cattle would be accounted for by the fact of the different breeds of animals with different rates of udder metabolism. The high rate of glucose metabolism accounted for the NADPH production in the pentose phosphate pathway during early and mid-lactation, which also associated with the high transfer of carbon atom of glucose to glycerol for the esterification in milk fat. The percentages of glycerol synthesized from glucose carbon (using $\mathrm{U}^{14} \mathrm{C}$ glucose as marker) in vivo, were lower than those reported in studies in vitro by Hardwick and co-worker (1963), in which $23 \%$ of triacylglycerol glycerol was synthesized from glucose in the perfused goat udder. The difference can be attributed to the fact that the glucose carbon taken up by the mammary gland in intact conscious animals can be accounted for synthesis of lactose, citrate, $\mathrm{CO}_{2}$ and lost as venous-plasma lactate. Some glucose may also be converted into amino acids for milk protein synthesis (Linzell \& Mepham, 1968). In 87.5\%HF cattle, the utilization of glucose 
carbon by mammary epithelial cells for the synthesis of triacylglycerol( using $\mathrm{U}-{ }^{14} \mathrm{C}$ glucose infusion) was lower in early lactation and conversely, the values expressed as percentages are higher during mid- and late lactation (Chaiyabutr et al 2000c). An increase in the proportion of ${ }^{14} \mathrm{C}$-glucose converted to triacylglycerol was consistent with a large proportion of glucose 6-phosphate which was metabolized via the Embden-Meyerhof pathway (EMP) in late lactation in $87.5 \% \mathrm{HF}$ cattle (Fig.5).

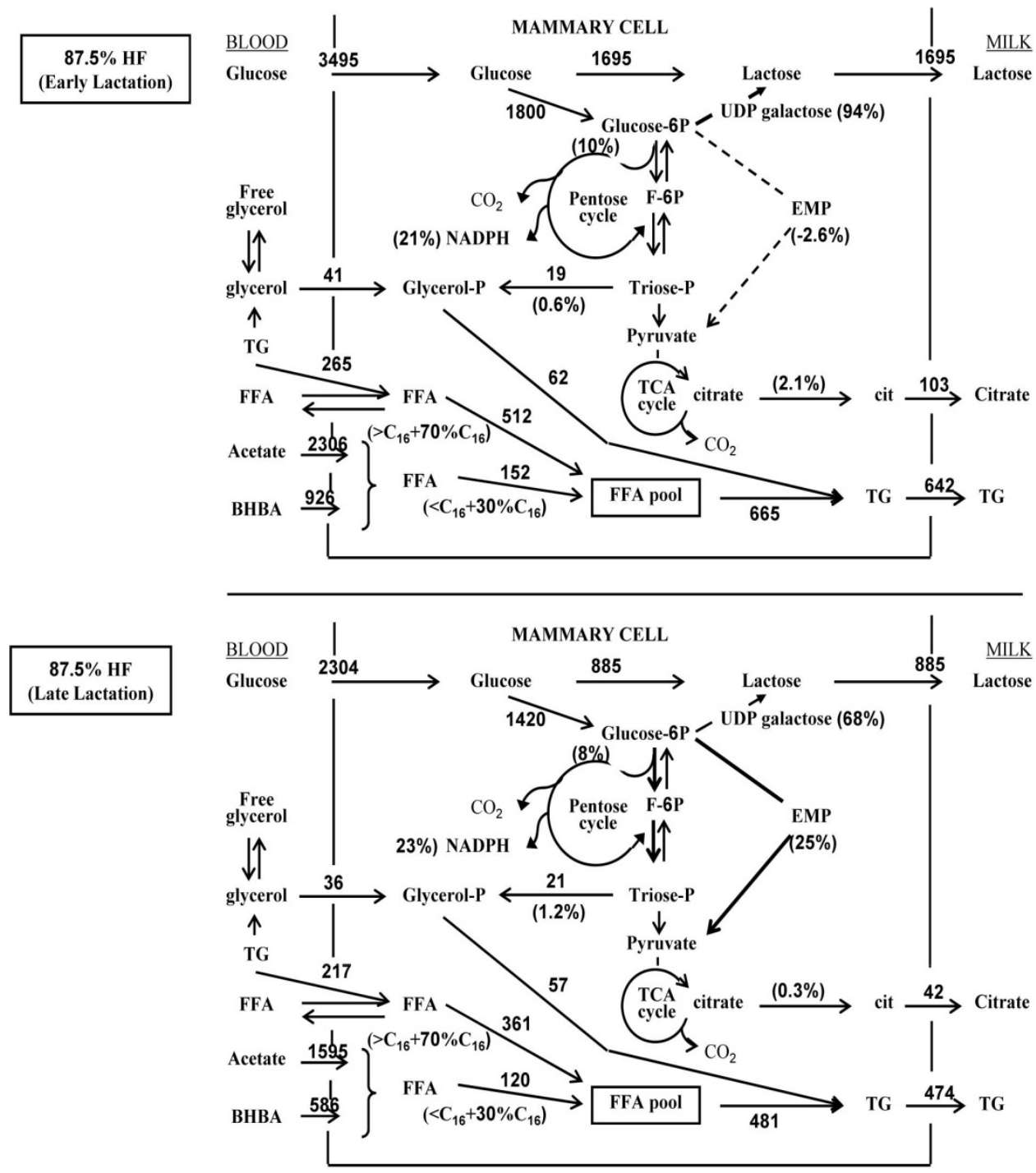

Figure 5. Scheme for calculated metabolic pathways involve intracellular partitioning of precursors of milk in mammary epithelial cells during early and late lactation of $87.5 \% \mathrm{HF}$ cattle. Values are shown in micromole/min. (Calculated data from Chaiyabutr et al 2000c) 


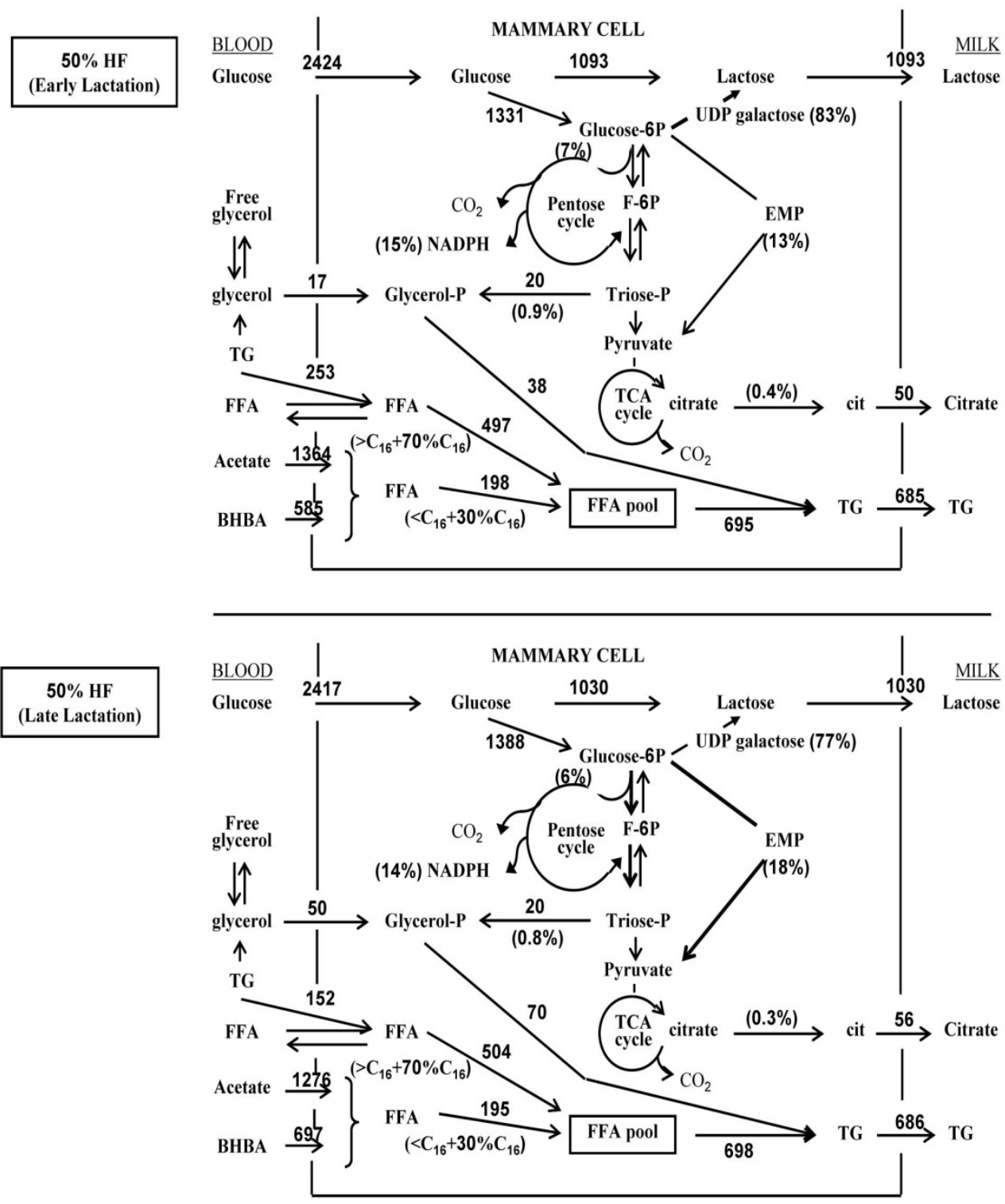

Figure 6. Scheme for calculated metabolic pathways involve intracellular partitioning of precursors of milk in mammary epithelial cells during early and late lactation of $50 \% \mathrm{HF}$ cattle. Values are shown in micromole/min. (Calculated data from Chaiyabutr et al 2000c)

It is known that acetate, $\beta$-hydroxybutyrate, long chain fatty acids of triacylglycrol and free fatty acid fractions of plasma are major precursor of milk fatty acids. The balance data for 
the utilization of both short chain and long chain fatty acid were performed by calculating their likely contribution to milk free fatty acid knowing its composition and subtracting these values from the measured uptake of the substrates (Fig.5 \& 6). Acetate and $\beta$ hydroxybutyrate were grouped together because both acetate and $\beta$-hydroxybutyrate were contributed to the synthesis of milk fatty acids up to and including $\mathrm{C}_{16}$ (Annison et al., 1968; Palmquist et al., 1969). In normally fed cattle, acetate is the main substrates for milk fat synthesis and $\beta$-hydroxybutyrate also make a more significant contribution to oxidative metabolism in the udder. There is a negligible oxidation of free fatty acid by the udder in normally fed animals (Bickerstaffe et al., 1974). The insignificant net uptake of free fatty acids by the mammary gland has been shown to be due to the simultaneous uptake of free fatty acids and release into mammary venous blood of fatty acid derived from plasma triacylglycerol which are hydrolysed during their uptake by the mammary gland (West et al., 1972). During mid- and late lactation of $87.5 \% \mathrm{HF}$ animals there are marked decreases in utilization of both acetate and $\beta$-hydroxybutyrate which are due to the decrease in their supplies from the blood stream (Chaiyabutr et al., 2002).

During early lactation, the milk fatty acid concentrations with a chain length of $\mathrm{C}_{6}$ to $\mathrm{C}_{18}$ of $50 \%$ HF cattle were higher than those of $87.5 \%$ HF cattle feeding on similar diet (Chaiyabutr et al 2000c). During mid- and late lactation, similar milk fatty acid concentrations were maintained as in early lactation of $50 \% \mathrm{HF}$ animals. There was considerable variation with advanced lactation in the level of milk fatty acid concentration of $87.5 \%$ HF cattle. During mid-lactation and late lactation, the milk fatty acid concentration, particularly with a chain length of $\mathrm{C}_{16}$ to $\mathrm{C}_{18}$, increased to the same level as that in $50 \% \mathrm{HF}$ animals.

\section{Role of changes of hormone supply}

It has been realized that during late pregnancy, lactogenesis occurs concurrently with mammary development and many hormones are needed for maximal stimulation of lactogenesis. There are many factors have been reported to capable of influencing lactation persistency in ruminant. The hormonal control of substrates uptake of the mammary gland and milk yield may be expected to occur in crossbred lactating cattle. However, the way in which hormones act is complex. The studies of Chaiyabutr et al (2000d) in measurements plasma hormone levels of different types of lactating crossbred cattle are shown in Table 1. There were no differences in the mean plasma thyroxine $\left(\mathrm{T}_{4}\right)$ concentrations during late pregnant period and lactating periods of experimental animals between $87.5 \% \mathrm{HF}$ and $50 \%$ HF cattle which were given the same period and identical rations. However, plasma triiodothyronine $\left(\mathrm{T}_{3}\right)$ concentrations of both types of crossbred HF cattle were lowered in late pregnancy as compared to lactating periods. The difference of the pattern of changes between $T_{3}$ and $T_{4}$ at the onset of lactation may be suggestive of an active and rapid transformation of $\mathrm{T}_{4}$ to $\mathrm{T}_{3}$ (Boonnamsiri et al 1979). The maintenance in high levels of plasma $\mathrm{T}_{3}$ concentrations throughout lactation suggested that $\mathrm{T}_{3}$ might act as an important factor in the regulation of lactation. 
Changes in endocrine status during the transition period from late pregnancy to lactation will influence metabolism and the nutritional status. The pattern of differences in insulin concentrations between late pregnancy and early lactation could not be attributed to diurnal variation (Bines et al., 1983) and feeding effect (Bassett 1974). The mean plasma insulin concentration of both $87.5 \% \mathrm{HF}$ and $50 \% \mathrm{HF}$ cattle increased during the lactating period as compared to the late pregnant and it remained constant in a higher level throughout the lactating period. An elevation of plasma insulin levels during the onset of lactation might be a factor involved in changes in glucose turnover rate (Chaiyabutr et al., 1998). However, the plasma glucose concentrations in $87.5 \% \mathrm{HF}$ and $50 \% \mathrm{HF}$ cattle did not coincide with an increase in the plasma insulin concentration throughout periods of lactation. The plasma glucose concentrations of $50 \% \mathrm{HF}$ cattle in both pregnant and lactating periods were higher than those of $87.5 \% \mathrm{HF}$ cattle. The hyperactivity of adrenal cortex to produce the higher levels of plasma cortisol in $50 \% \mathrm{HF}$ cattle might play a role for a rise of the plasma glucose level.

There is evidence that a lipogenic role will be expected for an elevation of plasma insulin levels during lactation by the documented fall in plasma FFA concentrations which occurred throughout lactation in crossbred HF cattle. During late pregnancy, low levels of the plasma insulin concentration coincided with higher level of plasma FFA concentrations. Several mechanisms can propose to contribute to the changes in lipogenesis, e.g. the movement of energy substrates away from the adipose tissues stores causing an elevation of plasma FFA during low levels of the plasma insulin (Yang \& Baldwin, 1973) or the decreases in the sensitivity of adipose tissue to insulin at the onset of lactation (Faulkner \& Pollock, 1990). During late pregnancy, mammary growth and foetus development could account for energy deficit relating to the elevation of plasma FFA concentrations. The depressed plasma insulin during late pregnancy might represent a part of the mechanism permitting mobilization of energy store. The higher level of plasma progesterone during pregnancy in both types of crossbred HF might be the other factors that contributed to an increase in plasma FFA concentration (Shevah et al., 1975). A marked elevation of plasma estradiol, primarily estrone, during late pregnancy and dramatic decreases after parturition in both $87.5 \% \mathrm{HF}$ and $50 \% \mathrm{HF}$ cattle, would decrease feed intake at the period of prepartum and developing high plasma FFA levels (Grummer et al., 1990).

The higher levels in plasma growth hormone $(\mathrm{GH})$ during late pregnancy in $50 \% \mathrm{HF}$ cattle could account for an increase in plasma FFA concentrations in comparison to those of $87.5 \% \mathrm{HF}$ cattle. During lactation advance to mid and late lactation in $87.5 \% \mathrm{HF}$ cattle, the decrease in the level of GH coincided with the decreases in the plasma FFA concentration and milk yield. The higher level of GH in early lactation of both $87.5 \% \mathrm{HF}$ animals might influence on mammary blood flow in this period. An increase in mammary blood flow will relate to increase milk yield by contributing to a partitioning of nutrients to the mammary gland (Davis \& Collier 1985; Peel et al., 1981). The control mechanism for the mammary function during transition period from pregnancy to lactation probably differed between $50 \% \mathrm{HF}$ and $87.5 \% \mathrm{HF}$ cattle. The higher level of GH during late pregnancy comparing to early lactation of $50 \% \mathrm{HF}$ appeared to have no effect on mammary blood flow. The 
triggering of mammary blood flow and lactogenesis will involve a complex interaction of hormonal events. In late pregnancy the onset of copious lactation is overcome by the inhibition action of progesterone. Falling concentrations of progesterone after parturition would release the mammary gland from this inhibition and the rate of milk synthesis and mammary blood flow rise to a value that becomes limited by new factors perhaps the actions of GH. Plasma prolactin concentrations vary within narrow limits and did not differ between $50 \% \mathrm{HF}$ and $87.5 \% \mathrm{HF}$ cattle either in late pregnancy or during lactation. It has been shown that circulating prolactin in cattle can be raised or lowered by day length (Bourne \&Tucker 1975 ) or ambient temperature (Wetteman and Tucker, 1974).

\begin{tabular}{|c|c|c|c|c|c|}
\hline Hormones & Cattle & Late pregnant & Early lactation & Mid lactation & Late lactation \\
\hline \multirow{2}{*}{$\begin{array}{l}\text { Triiodothyronine } \\
(\mathrm{ng} / 100 \mathrm{ml})\end{array}$} & $87.5 \% \mathrm{HF}$ & 87.8 & 100.5 & 114.8 & 114.8 \\
\hline & $50 \% \mathrm{HF}$ & 87.5 & 132.2 & 131.5 & 126.4 \\
\hline \multirow{2}{*}{$\begin{array}{l}\text { Thyroxine (T4) } \\
(\mu \mathrm{g} / 100 \mathrm{ml})\end{array}$} & $87.5 \% \mathrm{HF}$ & 3.66 & 3.67 & 3.94 & 3.69 \\
\hline & $50 \% \mathrm{HF}$ & 3.78 & 3.99 & 3.69 & 3.71 \\
\hline \multirow[t]{2}{*}{ Prolactin (ng/ml) } & $87.5 \% \mathrm{HF}$ & 4.38 & 5.31 & 6.10 & 8.51 \\
\hline & $50 \% \mathrm{HF}$ & 6.72 & 6.69 & 6.74 & 7.79 \\
\hline \multirow{2}{*}{$\begin{array}{l}\text { Growth hormone } \\
(\mathrm{ng} / \mathrm{ml})\end{array}$} & $87.5 \% \mathrm{HF}$ & 8.45 & 12.05 & 9.10 & 7.91 \\
\hline & $50 \% \mathrm{HF}$ & 15.16 & 9.03 & 8.76 & 9.76 \\
\hline \multirow[t]{2}{*}{ Cortisol (ng/ml) } & $87.5 \% \mathrm{HF}$ & 8.9 & 14.2 & 5.7 & 6.2 \\
\hline & $50 \% \mathrm{HF}$ & 6.8 & 29.2 & 25.3 & 35.9 \\
\hline \multirow{2}{*}{$\begin{array}{l}\text { Insulin } \\
(\mu \mathrm{U} / \mathrm{ml})\end{array}$} & $87.5 \% \mathrm{HF}$ & 12.35 & 18.65 & 23.71 & 21.06 \\
\hline & $50 \% \mathrm{HF}$ & 16.55 & 23.03 & 22.91 & 22.92 \\
\hline \multirow{2}{*}{$\begin{array}{l}\text { Glucagon } \\
(\mathrm{pg} / \mathrm{ml})\end{array}$} & $87.5 \% \mathrm{HF}$ & 41.8 & 54.7 & 82.7 & 65.5 \\
\hline & $50 \% \mathrm{HF}$ & 57.0 & 67.2 & 118.6 & 112.1 \\
\hline \multirow{2}{*}{$\begin{array}{l}\text { Progesterone } \\
(\mathrm{ng} / \mathrm{ml})\end{array}$} & $87.5 \% \mathrm{HF}$ & 3.85 & 0.38 & 0.72 & 2.27 \\
\hline & $50 \% \mathrm{HF}$ & 4.45 & 0.12 & 1.42 & 2.16 \\
\hline \multirow{2}{*}{$\begin{array}{l}\text { Estradiol } \\
(\mathrm{pg} / \mathrm{ml})\end{array}$} & $87.5 \% \mathrm{HF}$ & 122.4 & 14.0 & 11.9 & 14.2 \\
\hline & $50 \% \mathrm{HF}$ & 175.6 & 18.3 & 22.1 & 25.9 \\
\hline
\end{tabular}

Table 1. Concentrations of triiodothyronine, thyroxine, prolactin, growth hormone, Cortisol, insulin, glucagon, progesterone and estradiol in plasma of crossbred HF animals during late pregnancy and different stages of lactation. (From Chaiyabutr et al., 2000d)

\section{Other physiological responses in different stages of lactation in crossbred Holstein cattle}

The mechanisms that limit the rate of milk yield and shorter lactation persistency as lactation advances in crossbred dairy cattle in tropics are not only animal genetics that have 
to be considered but other factors, for example, high environmental temperatures and hormonal factors can influence milk production of cows (Collier et al., 1982). High environmental temperatures are known to affect milk secretion at various levels of mechanisms in dairy cattle both directly and indirectly. Thermal effect with heat stress will affect bodily functions of dairy cattle. Many technologies are required to improve milk production of dairy cattle in the tropics. Many studies have been done in attempting to improve dairy productivity by management strategies in high environmental temperatures. Environmental modification is the most common to reduce the impacts of high temperature for increase milk production, for example water spray with fans (Fike et al., 2002), or evaporative cooling system (Chan et al., 1997; Chaiyabutr et al., 2008). Bovine growth hormone or somatotropin (bST) is a homeorrhetic hormone connected with growth and lactation in ruminant (Bauman, 1992). The concentration of plasma bovine somatotropin (bST) in $87.5 \%$ HF cattle decreased rapidly as lactation progressed to mid and late lactation(Chaiyabutr et al., 2000d). This decrease would accompany with a reduction in both mammary blood flow and milk yield. Many studies have demonstrated the efficacy of bST for improvement in milk yield (Breier et al., 1991 ; Burton et al., 1994). Long term exogenous recombinant bovine somatotropin (rbST) in $87.5 \%$ crossbred Holstein cattle increased in milk yield which accompanied with an increase in the rate of mammary blood flow, but the stimulant effect for milk yield was less in late lactation despite a high level of mammary blood flow (Chaiyabutr et al. 2007). It is not known which factors are the cause and which factors are the effects for such reduction.

The additive effects of cooling and supplemental recombinant bovine somatotropin (rbST) in responsible for the short persistency of milk yield in crossbred Holstein cattle has been carried out in $87.5 \% \mathrm{HF}$ cattle. Long term exogenous recombinant bovine somatotropin $(\mathrm{rbST})$ in $87.5 \%$ HF cattle could increase the rate of mammary blood flow, total body water (TBW) and extracellular fluid (ECF) in association with an increase in plasma IGF-I (Chaiyabutr et al. 2005). An increase in mammary blood flow would contribute nutrients partitioning to the mammary gland for milk synthesis. Greater water retention during rbST administration would not only provide a greater reservoir of soluble metabolites for biosynthesis of milk, but it may be useful in slowing down the elevation in body temperature during heat exposure.

The milk yield of $87.5 \%$ HF cattle either under misty fan cooling or non-cooling increase after peak during supplemental rbST in early stage of lactation; thereafter milk yields continued to decline as lactation advanced, while mammary blood flow and body fluids volume increased during rbST supplementation in each stage of lactation in both cooled cow under misty fan and non-cooled cow (Sitprija et al.,2010). An increase in ECF by the effects of rbST in both cooled and non-cooled cows lead to an increase in MBF as secondary responses in facilitating increased milk production. However, changes in other bodily functions of crossbred cattle were also involved by effects of mist-fan cooling and supplemental rbST. In crossbred lactating cows, the response to rbST supplementation for milk production could be enhanced under mist-fan cooling. An increase milk production during rbST supplementation was mediated via increase in efficiency of feed utilization 
without changes in diets digestibility (Chanchai et al., 2010). Alterations of plasma hormones concentration especially IGF-I would increase during rbST supplementation in each stage of lactation in both cooled and non-cooled cows. The effect of exogenous rbST for increase in milk productions required IGF-I as a mediator to increase in mammary blood flow for increasing the availability of substrates to the mammary gland for milk synthesis.

\section{Conclusion}

The aim of this review is to highlight the regulatory mechanisms underlying marked low milk yields, by providing an updated summary of the results obtained concerning extramammary factors and intra-mammary factors of crossbred dairy cows in the tropic. In conclusion, the $87.5 \% \mathrm{HF}$ animal had the genetic potential for a high milk yield and homeorhetic adaptation for mammary function differed from $50 \% \mathrm{HF}$ animals during periods of lactation. Altering lactation persistency in $87.5 \% \mathrm{HF}$ was regulated mainly by chronically acting of growth hormones through the period of lactation. The utilization of glucose in the mammary gland was determined by measuring rates of glucose uptake and the incorporation of glucose into milk components in both groups of $50 \% \mathrm{HF}$ and $87.5 \% \mathrm{HF}$ cattle. In early lactation, there were no significant differences of the total glucose entry rate and glucose carbon recycling between crossbred cattle. The percentages and values of nonmammary glucose utilization increased during lactation advance in both $50 \% \mathrm{HF}$ and $87.5 \%$ HF cattle. The percentage of glucose uptake for utilization in the synthesis of milk lactose by the mammary gland of $87.5 \% \mathrm{HF}$ cattle was higher than $50 \% \mathrm{HF}$ cattle. Intracellular glucose6-phosphate metabolized via the pentose phosphate pathway accounted for the $\mathrm{NADPH}$ (reducing equivalent) of fatty acid synthesis in the mammary gland being higher in $87.5 \%$ HF animals during mid- lactation. A large proportion of metabolism of glucose via the Emden-Meyerhof pathway in the mammary gland was more apparent in $50 \% \mathrm{HF}$ cattle than $87.5 \%$ HF cattle during early and mid- lactation, while it markedly increased for $87.5 \%$ HF cattle during late lactation. The glucose utilization for biosynthetic pathways in the mammary gland of $50 \% \mathrm{HF}$ animals was maintained in a similar pattern throughout periods of lactation. A poorer lactation persistency of $87.5 \% \mathrm{HF}$ animals occurred during lactation advance, which was related to a decrease in the lactose biosynthetic pathway. As advanced lactation, local changes for biosynthetic capacity within the mammary gland would be a factor in identification of the utilization of substrates in the rate of decline in milk yield. The proportion of glucose would be metabolized less for lactose synthesis, but metabolized more via the Embden-Meyerhof pathway and the tricarboxylic acid cycle as lactation advances to late lactation.

\section{Author details}

Narongsak Chaiyabutr

Department of Physiology, Faculty of Veterinary Science, Chulalongkorn University, Bangkok, Thailand 


\section{References}

Annison, E.F.; Linzell, J.L. \& West, C.E. (1968). Mammary and whole animal metabolism of glucose and fatty acids in fasting lactating goats. Journal of Physiology, Vol. 197, pp. 445-459.

Bassett J.M. (1974). Diurnal patterns of plasma insulin, GH, corticosteriod and metabolite concentrations in fed and fasted sheep.Australian Journal of Biological Sciences, Vol. 27, pp. 167-168.

Bauman D.E. \& Currie W.B. (1980). Partitioning of nutrients during pregnancy and lactation: a review of mechanisms involving homeostasis and homeorhesis. Journal of Dairy Science, Vol. 63, pp. $1514-1529$.

Bauman D.E. (1992). Bovine somatotropin: review of an emerging animal technology. Journal of Dairy Science, Vol. 75, No. 3, pp. 3432-3451.

Bickerstaffe,R.; Annison,E.F. \& Linzell, J.L. (1974). The metabolism of glucose, acetate, lipids and amino acids in lactating dairy cows. Journal of Agricultural Science, Vol82, pp 71-85.

Bines, J.A.; Hart, I.C. \& Morant, S.V. (1983) Endocrine control of energy metabolism in the cow: diurnal variations in the concentrations of hormones and metabolites in the blood plasma of beef and dairy cows. Hormone and metabolic Research, Vol. 15. pp. 330-334.

Boonnamsiri, V.; Kermode, J.C. \& Thompson, B.D. (1979). Prolonged intravenous infusion of labelled iodocompounds in the rat: ${ }^{125} \mathrm{I}$ thyroxine and $\left({ }^{125} \mathrm{I}\right)$ triiodothyronine metabolism and extrathyroidol conversion of thyroxine to triiodothyronine. Journal of Endocrinology, Vol. 82, pp. 235-243.

Bourne, R.A. \& Tucker, H.A. (1975) Serum prolactin and LH responses to photoperiod in bull calves. Endocrinology, Vol. 97, pp. 473-475.

Breier, B.H.; Gluckman, P.D.; McCutcheon, S.N. \& Davis, S.R. (1991). Physiological responses to somatotropin in the ruminant. Journal of Dairy Science, Vol. 74 (suppl.2), pp. 20-34.

Burnol,A.F.; Leturque, A.; Loizeaau, M.; Postic, C., \& Girard, J. (1990). Glucose transporter expression in rat mammary gland. Biochemical Journal, Vol. 270, pp. 277-279.

Burton, J.L.; McBride, B.W.; Block, E.; Glimm, D.R. \& Kennelly, J.J. (1994).A review of bovine growth hormone. Canadian Journal of Animal Science, Vol. 74 pp. 167-201.

Chaiyabutr, N.; Faulkner, A. \& Peaker, M. (1980). The utilization of glucose for the synthesis of milk components in the fed and starved lactating goat in vivo. Biochemical Journal, Vol. 186 ,pp. 301-308.

Chaiyabutr, N.; Komolvanich, S.; Sawangkoon, S.; Preuksagoon, S. \& Chanpongsang, S. (1997). The regulation of body fluids and mammary circulation during late pregnancy and early lactation of crossbred Holstein cattle feeding on different types of roughage. Journal of Animal Physiology and Animal Nutrition, Vol. 77, pp. 167-179.

Chaiyabutr, N., Komolvanich, S.; Sawangkoon, S.; Preuksagorn, S.\& Chanpongsang, S. (1998). Glucose metabolism in vivo in crossbred Holstein cattle feeding on different types of roughage during late pregnancy and early lactation. Comparative Biochemistry and Physiology. Part A, Vol. 119, pp. 905-913.

Chaiyabutr,N.; Preuksagorn,S.; Komolvanich,S. \& Chanpongsang,S. (2000a). Comparative study on the regulation of body fluids and mammary circulation at different states of lactation in crossbred Holstein cattle feeding on different types of roughage. Journal of Animal Physiology and Animal Nutrition, Vol. 83, pp. 74-84. 
Chaiyabutr,N.; Preuksagorn, S.; Komolvanich, S. \& Chanpongsang, S.(2000b). Glucose metabolism in crossbred Holstein cattle feeding on two types of roughage at different stages of lactation. Comparative Biochemistry and Physiology. Part A, Vol. 125(1), pp.121-130.

Chaiyabutr,N.; Komolvanich, S.; Preuksagorn,S. \& Chanpongsang, S. (2000c). Comparative studies on the utilization of glucose in the mammary gland of crossbred Holstein cattle feeding on different types of roughage during different stages of lactation. AsianAustralasian Journal of Animal Science, Vol. 13(3), pp. 334-347.

Chaiyabutr,N.; Komolvanich,S.; Preuksagorn, S. \& Chanpongsang, S.(2000d). Plasma levels of hormones and metabolites as affected by the forages type in two different types of crossbred Holstein cattle. Asian-Australasian Journal of Animal Science, Vol. 13(10), pp. 1359-1366.

Chaiyabutr, N.; Thammacharoen, S.; Komolvanich, S. \& Chanpongsang, S. (2002). Studies on the mode of uptake of plasma glucose, acetate, $\beta$-hydroxybutyrate triglyceride fatty acids and glycerol by the mammary gland of crossbred Holstein cattle feeding on different types of roughage. Asian-Australasian Journal of Animal Science, Vol. 15(10), pp. 1445-1452.

Chaiyabutr, N.; Thammacharoen, S.; Komolvanich, S. \& Chanpongsang, S. (2005). Effects of long-term administration of recombinant bovine somatotropin on milk production and insulin like growth factor-I and insulin in crossbred Holstein cows. Journal of Agricultural Science (Cambridge), Vol. 143, pp. 311-318.

Chaiyabutr, N.;. Thammacharoen, S.; Komolvanich, S. \& Shanpongsang, S. (2007). Effects of long-term exogenous bovine somatotropin on water metabolism and milk yield in crossbred Holstein cattle. Journal of Agricultural Science ( Cambridge), Vol. 145, pp. 173-184.

Chaiyabutr, N.; Chanpongsang, S. \& Suadsong, S. (2008). Effects of evaporative cooling on the regulation of body water and milk production in crossbred Holstein cattle in a tropical environment. International Journal of Biometeorology, Vol. 52, pp. 575-585.

Chan, S.C.; Hubber J.T.; Chen K.H.; Simas J.M. \& Wu, Z. (1997). Effects of ruminally inert fat and evaporative cooling on dairy cows in hot environmental temperatures. Journal of Dairy Science, Vol. 80, pp. 1172-1178.

Chanchai, W.; Chanpongsang, S. \& Chaiyabutr,N. (2010). Effects of cooling and supplemental recombinant bovine somatotropin on diet digestibility, digestion kinetics and milk production of cross-bred Holstein cattle in the tropics. Journal of Agricultural Science ( Cambridge), Vol. 148, pp. 233-242.

Chase L.E., (1993). Developing nutrition programs for high producing dairy herds. Journal of Dairy Science, Vol. 76, pp. 3287-3293.

Collier, R.J.; Beede, D.K.; Thatcher, W.W.; Israel, L.A. \& Wilcox, C.J. (1982). Influences of environment and its modification on dairy animal health and production. Journal of Dairy Science, Vol 65, pp.2213-2227.

Coulon, J.B.; Perochon, L. \& Lescourret, F. (1995). Modelling the effect of the stage of pregnancy on dairy cow's milk yield. Journal of Animal Science, Vol. 60, pp. 401-408.

Davis, C.L. \& Bauman, D.E. (1974). General metabolism associated with the synthesis of milk. In: Lactation Vol. II, B.L. Larson,\& V.R Smith,(Eds.), pp. 3-30, Academic Press, New York and London.

Davis S.R, \& Collier R.J. (1985). Mammary blood flow and regulation of substrate supply for milk synthesis. Journal of Dairy Science, Vol. 68, pp. 1041-1058. 
Ebner, K. E. \& Schanbacher, F.L. (1974). Biochemistry of lactose and related carbohydrates. In: Lactation Vol. II,. B.L. Larson,\& V.R Smith,(Eds.), pp. 77-113, Academic Press, New York and London.

Faulkner, A. \& Peaker, M. (1987). Regulation of mammary glucose metabolism in lactation. In: The Mammary gland: development, regulation and function, M.C. Neville \& Daniel CW (Eds.), pp 535-562,Plenum Press, New York.

Faulkner, A. \& Pollock, H.T. (1990). Metabolic responses to euglycaemic hyperinsulinaemia in lactating and non-lactating sheep in vivo. Journal of Endocrinology, Vol. 124, pp. 59-66.

Fike, J.H.; Staples, C.R.; Sollenberger, L.E.; Moore, J.E. \& Head, H.H. (2002). Southeastern pasture-based dairy systems: housing, posilac, and supplemental silage effects on cow performance. Journal of Dairy Science, Vol. 85, pp. 866-878.

Grummer, R.R.; Bertics, S.J.; LaCount, D.W.; Snow, J.A.; Dentine, M.R. \& Staauffacher, R.H. (1990). Estrogen induction of fatty liver in dairy cattle. Journal of Dairy Science, Vol. 73, pp 1537.

Hahn, G.L.; Mader, T.L.; Gaughan, J.B.; Hu, Q. \& Nienaber, J.A. (1999). Heat waves and their impacts on feedlot cattle, Proceedings of $15^{\text {th }}$ International Society Biometerology congress, Sydney, Australia, September, pp. 353-357.

Hanwell, A. \& Peaker, M. (1977). Physiological effects of lactation on the mother. In: Comparative Aspects of Lactation, M. Peaker, (Ed.), pp.297-312, The Zoological Society of London, Academic Press.

Hardwick, D.C.; Linzell, J.L. \& Price, S.M. (1961). The effect of glucose and acetate on milk secretion by the perfused goat udder. Biochemical Journal, Vol.80, pp.37-45.

Hardwick, D.C.; Linzell, J.L. \& Mepham, T.M. (1963). The metabolism of acetate and glucose by the isolated perfused udder 2 . The contribution of acetate andglucose to carbondioxide and milk constituents. Biochemical Journal, Vol.88, pp.213-220..

Hart, I.C. (1973). Effect of 2-Bromo-2-ergocryptine on milk yield and the level of prolactin and growth hormone in the blood of the goat at milking. Journal of Endocrinology. Vol. 57, pp.179-180.

Hart, I.C.; Lawrence, S.E. \& Mepham, T.B. (1980). Effect of exogenous growth hormone on mammary blood flow and milk yield in lactating goats. Journal of Physiology, Vol. 46, pp. 308.

Horsfield, S.; Infield, J.M. \& Annison, E.F. (1974). Compartmental analysis and model building in the study of glucose kinetics in the lactation cow. Proceedings of the Nutrition Society, Vol. 33, No.1, pp.9-15.

Jayasuriya, M.C.N. \& Perera, H.G.D. (1982). Urea-ammonia treatment of rice straw to improve its nutritive value for ruminants. Agricultural Wastes, Vol.4, pp.143-150.

Jones, E.A. (1978). Lactose Biosynthesis. In: Lactation Vol. II, B.L. Larson,\& V.R Smith,(Eds.), pp. 371-385, Academic Press, New York and London.

Komatsu, T.; Itoh, F.; Kushibiki, S. \& Hodate K. (2005). Changes in gene expression of glucose transporters in lactating and nonlactating cows. Journal of Animal Science, Vol. 83, pp. 557-564.

Kaufmann, W. \& Hagemeister, H. (1987). Composition of milk. In: Dairy-cattle production, H.O. Gravert (Ed), pp 107-171, Elsevier Science Publishers BV, Amsterdam.

Kuhn, N.J.; Carrick, D.T. \& Wilde, C. J. (1980). Milk synthesis. Journal of Dairy Science, Vol. 63, pp 328-336. 
Lacasse, P.; Farr, V.C. ; Davis, S.R. \& Prossser, C.G. (1996). Local secretion of nitric oxide and the control of mammary blood flow. Journal of Dairy Science, Vol 79, pp.1369-1374.

Leng, R. A. and C. E. West. 1969. Contribution of acetate, butyrate, palmitate, stearate and oleate to ketone body synthesis in sheep. Research in Veterinary Science, Vol. 10, pp.57-63.

Lindsay, D.B. (1973). Metabolic changes induced by pregnancy in the ewe. In: Production disease in farm animals, E.J.M. Payne; K.G. Hibitt \& B.F. Sansom, (Eds). pp.107-114, Bailliere, Tindal, London.

Linzell, J.L. \& Mepham, T. B. (1968). Mammary synthesis of amino acids in the lactating goat. Biochemical Journal, Vol.107, pp.18-19.

Linzell, J.L. \& Peaker, M. (1971). Mechanisms of milk secretion. Physiological Review, Vol. 51, pp.564-597.

Linzell, J.L. (1968). The magnitude and mechanisms of the uptake of milk precursors by the mammary gland. Proceedings of the Nutrition Society, Vol. 27, pp. 44-52.

Linzell J.L. (1973). The demands of the udder and adaptation to lactation. In: Production disease in farm animals,J.M. Payne; K.G. Hibbitt \& B.F. Sansom (Eds.),pp 89-106, Bailliere, Tidal, London.

Linzell, J. L. \& Mepham, T. B. (1974). Effect of intramammary arterial infusion of essential amino acids in the lactating goat. Journal of Dairy Science, Vol. 41, pp. 101-109.

Linzell, J.L. (1974). Mammary blood flow and methods of identifying and measuring precursors of milk. In: Lactation Vol. II, B.L. Larson,\& V.R Smith,(Eds.), pp. 143-225, Academic Press, New York and London.

MacFarlane, M.V. a\& Howard, B. (1970). Water in the physiological ecology of ruminants. In: Physiology of digestion and metabolism in Ruminants. Phillipson, A.T. (Ed.), pp. 362-374, Oriel Press, Newcastle upon Tyne.

Mepham, T. B. (1993). The development of ideas on the role of glucose in regulating milk secretion. Australian Journal of Agricultural Research, Vol.44, pp. 508-522.

Murphy, M. R. (1992). Symposium: Nutritional factors affecting animal water and waste quality. Journal of Dairy Science, Vol.75, pp 326-333.

Nakamura, R.M.; Araki, C.T. \& Chaiyabutr, N. (1993). Temperate dairy cattle for hot climates: Telemetry studies and strategy. In: Livestock Environment IV, Fourth International Symposium, pp.16-22, University of Warwick, England.

Palmquist, D.L.; Davis, C.L.; Brown, R.E. \& Sachan, D.S.(1969). Availability and metabolism of various substrates in ruminants. V. Entry rate into the body and incorporation into milk fat of D(-)- $\beta$ - hydroxybutyrate. Journal of Dairy Science, Vol. 52, pp. 633-638.

Peel, C.J.D.; Bauman, D.E.; Gorwit, R.C. \& Sniffen,C.J.(1981). Effect of exogenous growth hormone on lactational performance in high yielding dairy cows. Journal of Nutrition, Vol.111, pp.1662-1671.

Promma, S.; Tasaki, I.; Cheva-Isarakul, B. \& Indratula, T. (1994). Digestibility of Neutralized urea-treated rice straw and nitrogen retained in crossbred Holstein streers. AsianAustralasian Journal of Animal Science, Vol. 7(4), pp. 487-491.

Ranjhan, S.K.; KalanidhI, A.P.; Gosh, T.K.; Singh, U.B. \& Saxena, K.K. (1982). Body composition and water metabolism in tropical ruminants using tritiated water. In: Use of Tritiated Water in Studies of Production and Adaptation in Ruminants. pp 117-132. International Atomic Energy Agency, Vienna. 
Reid, R. L. \& Hinks, N. T. (1962). Studies on the carbohydrate metabolism of sheep, XVIII. The metabolism of glucose, free fatty acid, ketones and amino acids in late pregnancy and lactation. Australian Journal of Agricultural Research, Vol. 13, pp.1112-1123.

Rook, J.A.F. \& Wheelock, J.V. (1967). The secretion of water and water soluble constituents in milk. Journal of Dairy Research. Vol. 34, pp. 273-287.

Shevah, Y.; Black, W.J.M.; Carr, W.R. \& Land, R.B. (1975). The effects of nutrition on the reproductive performance of Finnx Dorset ewes. 1. Plasma progesterone and LH concentrations during late pregnancy. Journal of Reproductive Fertility, Vol. 45, pp.283-288.

Shirley, J. E.; Emerry, R. S.; Convey, E. M \& Oxender, W. D. (1973). Enzymic changes in bovine adipose and mammary tissue, serum and mammary tissue hormonal changes with initiation of lactation. Journal of Dairy Research, Vol 56, pp.569-574.

Sitprija, S.; Chanpongsang, S.\& Chaiyabutr, N. (2010). Effects of Cooling and Recombinant Bovine Somatotropin Supplementation on Body Fluids, Mammary Blood Flow, and Nutrients Uptake by the Mammary Gland in Different Stages of Lactation of Crossbred Holstein Cattle. Thai Journal of Veterinary Medicine, Vol. 40, pp.195-206.

Sölkner, J. \& Fuchs, W. (1987). A comparison of different measures of persistency with special respect to variation of test-day milk yields. Livestock Production Science Vol.16, pp.305-319.

Thompson, G.E. \& Thomson E.M. (1977). Effect of cold exposure on mammary circulation oxygen consumption and milk secretion in the goat. Journal of Physiology Vol. 272 (1), pp.187-196.

Tucker, H.A. (1981). Physiological control of mammary growth, lactogenesis and lactation. Journal of Dairy Science, Vol. 64, pp.1403-1421.

Tucker, H.A.(1987). Quantitative estimates of mammary growth during various physiological states: a review. Journal of Dairy Science, Vol. 70, pp.1958-

West, C.E.; Annison, E.F. \& Linzell, J.L. (1967). Plasma free fatty acid uptake and release by the goat mammary gland. Biochemical Journal, Vol. 102: 23P.

West, C.E.; Bickerstaffe, R.; Annison, E.F. \& Linzell, J.L. (1972). Studies on the mode of uptake of blood triglycerides by the mammary gland of the lactating goat. The uptake and incorporation into milk fat and mammary lymph on labelled glycerol, fatty acids and triglycerides. Biochemical Journal, Vol 126, pp. 477-490.

Wetteman, R.P. \& Tucker, H.A. (1974). Relationship of ambient temperature to serum prolactin in heifers. Proceedings Society of Experimental Biology and Medicine, Vol.146, pp.908-911.

Wood, H.G.; Peeters, G.J.; Verbeke, R.; Lauryssens, M. \& Jacobson, B. (1965). Estimation of the pentose cycle in the perfused cow's udder. Biochemical Journal, Vol.96, pp.607-615.

Xiao, C.; Cant, J.P. (2003).Glucose transporter in bovine mammary epithelial cells is an asymmetric carrier that exhibits cooperativity and trans-stimulation. American Journal of Physiology, Cell Physiolology, Vol.285, pp. C1226-C1234.

Yang, Y.T. \& Baldwin, R.L. (1973). Lipolysis in isolated cow adipose cells. Journal of Dairy Science, Vol 56, pp.366-374.

Zhao, F.Q.; Moseley, W.M.; Tucker, H.A. \& Kennelly, J.J. (1996). Regulation of glucose transporter gene expression in mammary gland, muscle, and fat of lactating cows by administration of bovine growth hormone and bovine growth hormone-releasing factor. Journal of Animal Science, Vol.74, pp.183-189. 